\title{
Transcranial Approach for Spontaneous CSF Rhinorrhea due to Sternberg's Canal Intrasphenoidal Meningoencephalocele: Case Report and Review of the Literature
}

\author{
Stenberg Kanalina Yerleşen ve Spontan Rinoreye Neden Olan \\ Meningoensefalosele Transkranial Yaklaşım: Olgu Sunumu ve \\ Literatür Taramast
}

Mohammad SAMADIAN ${ }^{1}$, Habibollah MOGHADDASI ${ }^{2}$, Mohsen VAZIRNEZAMI ${ }^{2}$, Karim HADDADIAN ${ }^{1}$, Omidvar REZAEE ${ }^{1}$, Mehran ARMANFAR ${ }^{1}$, Fatemeh KHORMAEE ${ }^{3}$

${ }^{1}$ Loqman-Hakim Hospital, Shahid Beheshti University M.C., Department of Neurosurgery, Tehran, Islamic Republic of Iran

${ }^{2}$ Logman-Hakim Hospital, Shabid Beheshti University M.C., Department of ENT, Head and Neck Surgery, Tehran, Islamic Republic of Iran

${ }^{3}$ Logman-Hakim Hospital, Shahid Beheshti University M.C., Department of Emergency, Tehran, Islamic Republic of Iran

Correspondence address: Mohammad SAMADIAN / E-mail: mdsamadian@hotmail.com

\begin{abstract}
One type of congenital intrasphenoidal meningoencephalocele is remnant of lateral craniopharyngeal (Sternberg's) canal. We present a case of a 23-year girl with 10-month history of right side CSF rhinorrhea. CT scan, MRI revealed congenital meningoencephalocele and CSF leak from middle fossa to right side of sphenoid sinus, and there were bony defects at the floor of the anterior aspect of the right middle fossa. Transcranial repair was performed with right side pterional craniotomy. Careful preoperative evaluation and localization of the sphenoid defect are essential for selection of the best possible surgical approach and skull base reconstruction for repair of sphenoid sinus CSF leaks and meningoencephaloceles. In this case, an endoscopic technique was not successful so, transcranial repair was performed with right side pterional craniotomy.
\end{abstract}

KEYWORDS: Meningoencephalocele, Rhinorrhea, Transcranial repair

öz

Sfenoid kanat içine yerleşmiş meningoensephalosel, lateral kraniofarengial kanalın (Stenberg'in kanalı) artığından meydana gelen bir konjenital anomalidir. Sağ burun deliğinden 10 aydan beri BOS gelen 23 yaşında kadın olgu olarak sunulmuştur. Bilgisayarlı tomografi ve manyetik rezonans görüntülemede; sağ orta fossa tabanının anterior yüzündeki kemik defekti ile sfeneoid sinüsün sağ tarafı arasında ilişki bulunmuştur. Sağ piterional kraniotomi yapılarak; kranial yoldan kemik defekti onarıldı. Sfenoid sinüsden BOS kaçağı olan ve meningoensefeloseli olan hastalarda ameliyat öncesi dönemde detaylı görüntüleme çalışmaları ile defekt ortaya konmalı ve en iyi cerrahi yaklaşım yolu bu görüntüleme çalışmalarına göre belirlenmelidir. Olgumuzda endoskopik girişimin başarısız olması nedeni ile sağ piterional kraniotomi yapılarak defekt onarımı yapılmıştır.

ANAHTAR SÖZCÜKLER: Meningoensefalosel, Rinore, Kranial yoldan onarım

INTRODUCTION

A meningoencephalocele is an uncommon malformation described by a protrusion of cerebral tissue and meninges through a congenital defect in the cranial bones. Serious complications from this condition usually happen In the first few years $(10,11,21)$ but occasionally symptoms do not occur until adulthood $(15,24)$.

We report here an adult case of Sternberg's canal intrasphenoidal meningoencephalocele with a 10-month history of right side CSF rhinorrhea.

\section{Clinical details}

A 23-year girl with a 10-month history of right side CSF rhinorrhea was referred to the neurosurgery clinic. Neuroimaging studies included coronal and axial paranasal multislice CT scan with 3D reconstruction of skull base, MRI and CT cisternography and showed sphenoid sinuses overpneumatization with extension tothe parasellar region. There was a well-defined bony defect containing CSF at the right parasellar region just lateral to the rotundum foramen measuring $3 \mathrm{~mm}$ that communicated with the anterior 
aspect of right middle cranial fossa and extended tothe right sphenoid sinus. The bony defect was a remnant of the craniopharyngeal canal (Sternberg's canal) (Figures 1, 2, 3).

She was a candidate for endoscopic repair of the meninoencephalocele. Endoscopic transethmoidal - pterygoidal - sphenoidal repair was performed. We tried to repair the defect with the endoscopic approach. Because of very lateral extension of the defect we did not have good view of the defect, and with standard endoscopic instrument the acute angleof the working area was not accessible. Then transcranial repair was performed with right side pterional craniotomy. With right side standard craniotomy with an intradural approach,

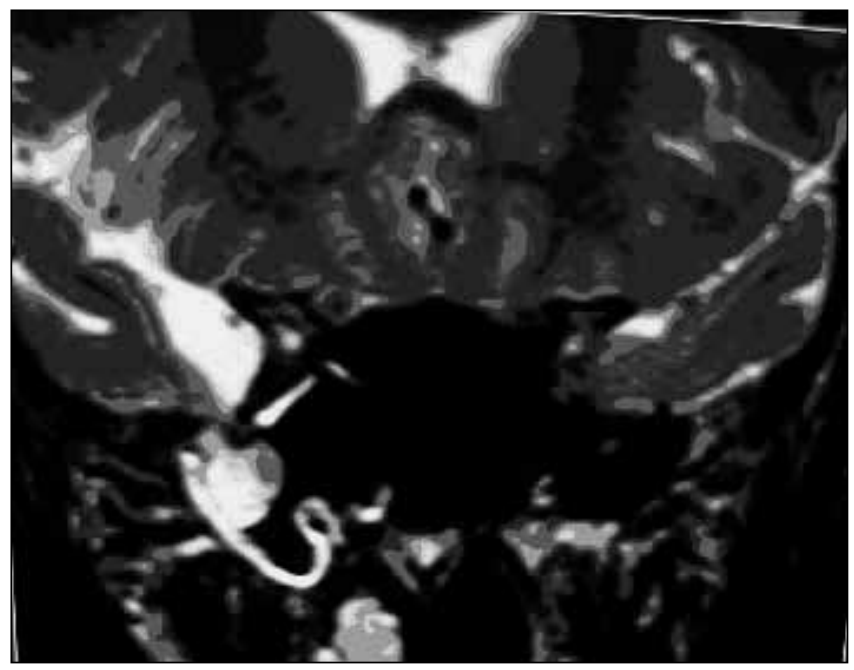

Figure 1: Coronal T2W MRI shows communication of the middle fossa with the sphenoid sinus via a bony defect. Brain, meninges and CSF protruded from the middle fossa to the RT sphenoid sinus.

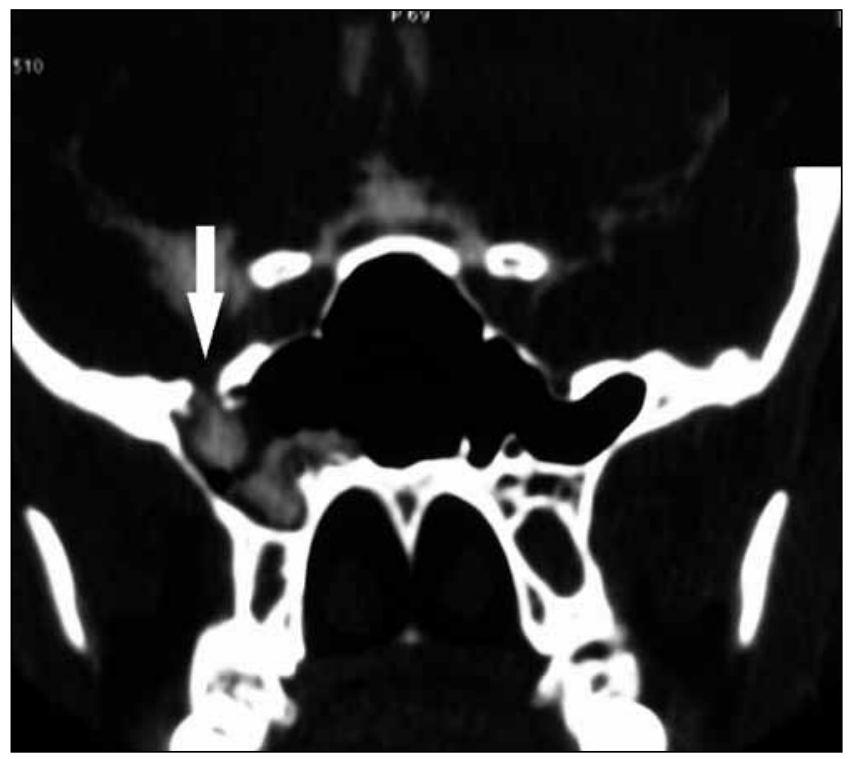

Figure 2: Coronal CT cisternography of patient; Overpneumatization of sphenoid sinus and CSF leak from middle fossa to RT sphenoid sinus through small bony defect (arrow) were seen. dissection was performed in the subtemporal region in the middle fossa. The bony defect was seen including part of the brain and meninges that protruded into the sphenoid sinus.

The soft tissue mass was amputated and the bony defect repaired with a small cranial bone graft and duraplasty was performed with fascia of temporalis muscle. Dura and craniotomy closure was performed with the standard method. The postoperative state was uneventful and she was discharged from the hospital after 3 days without any neurological deficit or CSF rhinorrhea. Post op MRI showed that the defect was well repaired (Figure 4). In follow-up for one year she is in good condition without CSF leak.

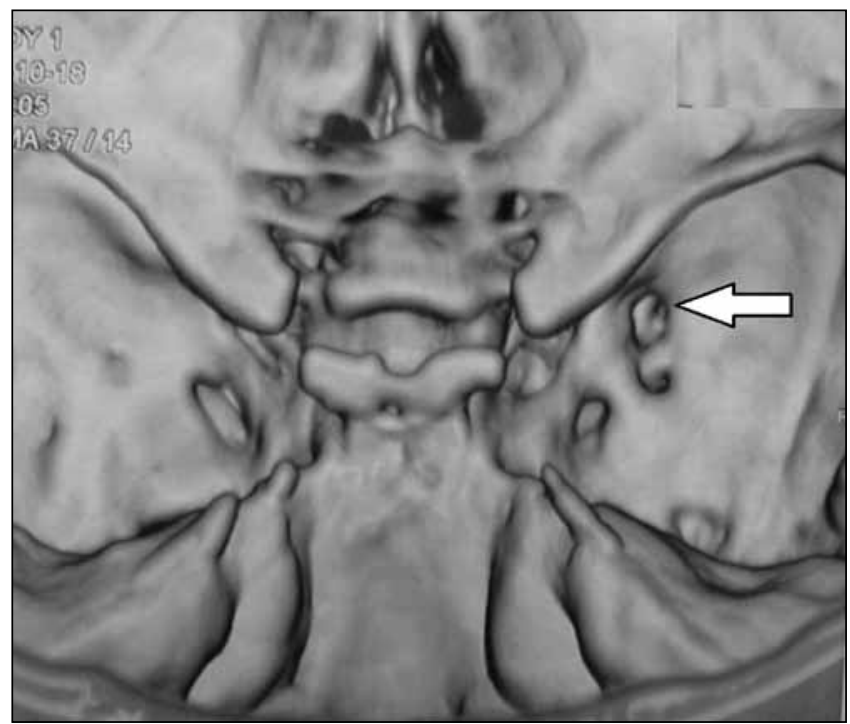

Figure 3: 3D reconstructed multislice $C T$ scan of skull base shows intracranial view of skull base and bony defect anterolateral to foramen rotundum (arrow).

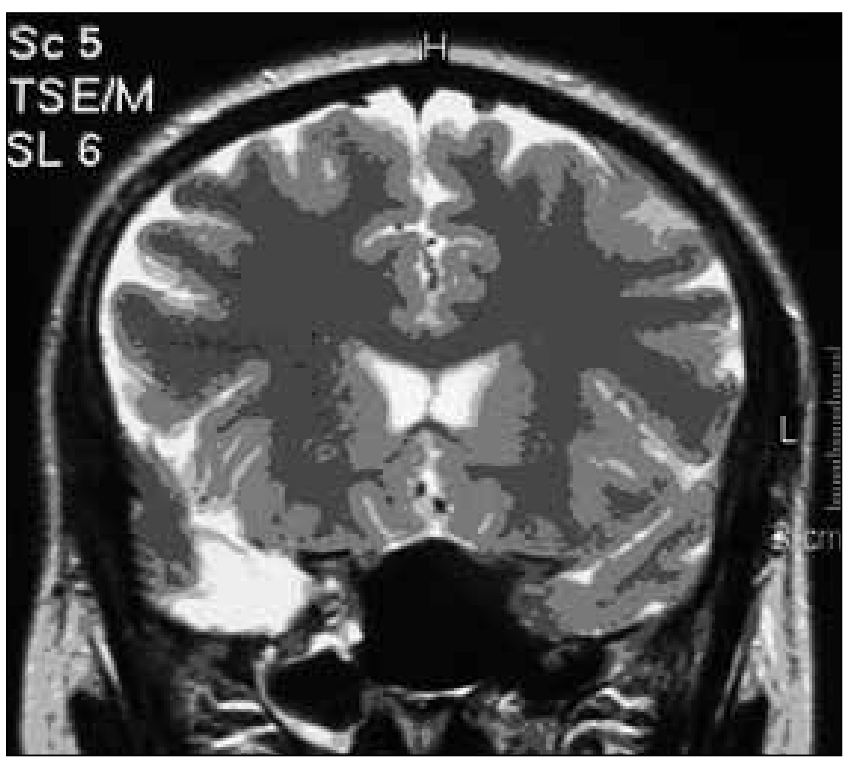

Figure 4: Coronal T2W MRI shows good repair of the defect. 


\section{DISCUSSION}

The incidence of cephaloceles (meningoceles, encephaloceles) is assumed to range between 1 and 3 in 10,000 children $(7,19)$. Occipital, sincipital (nasofrontal, nasoethmoidal, nasoorbital), and basal (sphenoorbital, sphenomaxillary, transethmoidal, sphenoethmoidal, sphenonasopharyngeal, basioccipital) cephaloceles can be distinguished in relation to the site of origin (16). A rare finding is a basal cephalocele that is limited to the sphenoid sinus and has been proposed to present a further subtype of basal cephaloceles (3).

It may be difficult to determine the accurate etiology of cephaloceles especially if no trauma is evident in the patient's history. Generally, non-traumatic cephaloceles include congenital and acquired forms (4).

Clinically, transsphenoidal encephaloceles are the only congenital type found in the sphenoid sinus. Abiko et al. (1). further distinguished two types of transsphenoidal meningoencephaloceles: the true transsphenoidal and the intrasphenoidal. The first one describes meningoencephaloceles extending into the sphenoid sinus but restricted by its floor. The latter describes encephaloceles traversing the floor of the sphenoid sinus and protruding into the nasal cavity or nasopharynx. Abnormalities of the face will most commonly coexist with the true transsphenoidal-type encephaloceles, which are transmitted through the sphenoid bone, optic system, and brain, corresponding to the median cleft face syndrome (14). In the early infantile period, high surgical risks may be encountered with transsphenoidal encephaloceles as the pituitary-hypothalamic structures are usually incorporated in the herniated encephaloceles of this age group $(12,18)$. Most patients present during childhood, Cases diagnosed in later adult life are rare $(15,24)$.

Generally, non-traumatic cephaloceles include congenital and acquired forms. One type of congenital intrasphenoidal meningoencephalocele is a remnant of the craniopharyngeal (Sternberg's) canal. The complex ontogeny of the sphenoid bone and the embryological conditions can cause the development of congenital sphenoidal cephaloceles (17, 20). During embryological development, the anterior sphenoid bone (presphenoid), the lesser wings, the posterior sphenoid bone (basisphenoid), the greater wings and the lateral pterygoid processes are built up first as independent cartilaginous precursors. At the third month of fetal life ossification of the cartilaginous precursors starts from 18 to 19 ossification centers (22).

Union of the various ossified components results in formation of the complex sphenoid bone (16). Bony fusion of the greater wings with the presphenoid/basisphenoid starts in its anterior portion. Posteriorly fusion can be incomplete, creating a lateral craniopharyngeal canal (Sternberg's canal). Sternberg's observations showed incomplete fusion of the greater wings and presphenoid in lower mammals (e.g. Paradigitatae).The development of the sphenoid sinus starts with fusion of the sphenoid turbinates (ossicula Bertini) and sphenoid bone. At the age of 3 to 4 years this connection is expected (23).
The shape of the later sphenoid sinus depends on the various extent of pneumatization due to bone absorption. A congenital bony defect resulting from incomplete fusion of the different sphenoid bone components can communicate with the sphenoid sinus after the necessary pneumatization has taken place. However, as extensive pneumatization of the sphenoid sinus usually results in only a thin bony border to the intracranial space, the prevalence of the sphenoid sinus border disorders in the development of acquired bony dehiscences has to be considered (13). It is important to take into account that fusion planes offer special resistance to pneumatization to differentiate between a congenital and an acquired non-traumatic bony defect in the sphenoid sinus. Consequently, sphenoidal cranial base defects at fusion planes are more likely to be of congenital origin than the acquired type. The lateral craniopharyngeal canal (Sternberg's canal) may act as the site of origin of congenital meningoceles or cerebrospinal fluid fistulas when there is sufficient sphenoid sinus pneumatization (26).

Traumatic or spontaneous CSF rhinorrhea make up 4\% of the cases. These are subdivided into normal pressure and high pressure leaks. High-pressure leaks include tumors and hydrocephalus. They are due to long-standing increases in intracranial pressure and account for $45 \%$ of spontaneous leaks. Increased pressure in the subarachnoid space forces CSF through a weak or potential pathway. Normal pressure leaks account for $55 \%$ of cases. They are thought to be due to slow erosion of the skull base secondary to normal fluctuations in intracranial pressure leading to point erosion and CSF rhinorrhea. $90 \%$ originate from a congenital or potential pathway such as a persistent craniopharyngeal canal. Direct erosion of the skull base by tumor or infections make up the remaining $10 \%$. In either case, the initial leak is frequently precipitated by coughing, sneezing or straining (22).

CT cisternography, 3D reconstructed multislice CT scan and MRI provide excellent three-dimensional definition of the lesion useful for both diagnosis and surgical planning $(2,5)$, and to classify other related intracranial anomalies.

The treatment of intranasal basal meningoencephaloceles is solely surgical. Although the first successful operation for intranasal meningoencephalocele was performed via a transmaxillary route (6), an intracranial approach have been widely adopted more recently $(10,11,15,21,22,24)$ as well.

If the defect in the skull base is small, an endoscopic transnasal approach can be considered to reduce surgical complications (25). The endoscopic approach also provides the most flexibility for visualization and exact localization of the defect site. However, in some cases like our case, the endoscopic approach may be unsuccessful. Failure with the endoscopic approach may be related to inaccurate localization of the defect, insufficient graft size and its displacement, incomplete apposition of the graft to the skull base defect, and noncompliance of the patient with post-operative instructions (9). Before deciding on the operative approach, the site and size of the meningoencephalocele and the associated 
malformations should be properly determined by detailed neuroradiological examination

\section{CONCLUSION}

Careful preoperative assessment and localization of the sphenoid defect and a thorough understanding of underlying etiologies are necessary in the selection of the best possible surgical approach and skull base rebuilding for repair of sphenoid sinus CSF leaks and meningoencephaloceles. In this case, endoscopic technique was not successful and transcranial repair was therefore performed with right side pterional craniotomy.

\section{ACKNOWLEDGEMENT}

The authors would like to thank Farzan Institute for Research and Technology for technical assistance.

\section{REFERENCES}

1. Abiko $\mathrm{S}$, Aoki $\mathrm{H}$, Fudaba $\mathrm{H}$ : Intrasphenoidal encephalocele. Neurosurgery 22: 933-936, 1988

2. Blaivie C, Lequeux T, Kampouridis S, Louryan S, Saussez S: Congenital transsphenoidal meningocele: Case report and review of the literature. Am J Otolaryngol 27:422-424, 2006

3. Daniilidis J, Vlachtsis K, Ferekidis E, Dimitriadis A: Intrasphenoidal encephalocele and spontaneous CSF rhinorrhea. Rhinology 37: 186-189, 1999

4. David D J: Cephaloceles classification pathology and management: A review. J Craniofac Surg 4:192-202, 1993

5. Diebler C, Dulac O: Cephaloceles clinical and neuroradiological appearance associated cerebral malformations. Neuroradiology 25: 199-216, 1983

6. Fenger C: Basal hernias of the brain. Am J Med Sci 62: 1-17, 1895

7. Giunta G, Pappagallo G, Piazza I, Girardi A: A rare case of recurrent meningitis: Intranasal encephalocele. Minerva Med 81:577-581, 1990

8. Graf von SF: Keilbein Ossphenoidale. In von Bardeleben K, Disse J (eds) Skelettlehre. Handbuch der Anatomie. Jena: Fischer Verlag 1896: 125-148

9. Greenberg J: Cerebrospinal Fluid Rhinorrhea. Available from: http://www.bcm.edu/oto/grand/120398.html. Access 1 May 2010

10. Hayashi T, Hashimoto T, Anegawa S, Utsunomiya $\mathrm{H}$ : Transethmoidal encephalomeningocele in neonate: Report of two cases and review of literatures. No To Shinkei 42: $175-182,1990$

11. Izquierdo M, Gil-Carcedo LM: Recurrent meningitis and transethmoidal intranasal meningoencephalocele. Dev Med Child Neurol 30: 248-251, 1988
12. Jabre A, Tabbaddor R, Samaraweera R: Transsphenoidal meningoencephalocele in adults. Surg Neurol 54: 183-188, 2000

13. Kaufman B, Nulsen FE, Weiss MH, Brodkey JS, White RJ, Sykora GF: Acquired spontaneous, nontraumatic normalpressure cerebrospinal fluid fistulas originating from the middle fossa. Radiology 122:379-387, 1977

14. Kitakara Y, Tagaki H, Ichikava F, Yamada M, Ootsuka E: Basal encephalocele: A report of two cases and consideration of its pathogenetic classification. No shinkei Geka 16:983-988, 1988

15. Kumar KK, Ganapathy K, Sumathi V, Rangachari V, Sundararajan I, Govindaraj R: Adult intranasal meningoencephalocele presenting as a nasal polyp. J Clin Neurosci 12:594-596, 2005

16. Nager G T: Cephaloceles. Laryngoscope 97:77-84, 1987

17. Peltonen E, Sedlmaier B, Brock M, Kombos T: Persistent cerebrospinal fluid rhinorrhea by intrasphenoidal encephalocele Zentralbl Neurochir 69:187-190, 2008

18. Peter J C, Fieggen G: Congenital malformations of the brain: A neurosurgical perspective at the close of the twentieth century. Childs Nerv Syst 15: 635-645, 1999

19. Rowland CA, Correa A, Cragan JD, Alverson CJ: Are encephaloceles neural tube defects? Pediatrics 118:916-923, 2006

20. Schick B, Brors D, Prescher A: Sternberg's canal--cause of congenital sphenoidal meningocele. Eur Arch Otorhinolaryngol 257:430-432, 2000

21. Sekerci Z, lyigün O, Bariş S, Cokluk C, Bozkurt G, Rakunt C, Celik F: Intranasal (transethmoidal) encephalomeningocele. Case report. Neurosurg Rev 18:123-126, 1995

22. Starck D: Embryologie. Stuttgart: Thieme-Verlag, 1975: 582603

23. Van Alyea OE: Sphenoid sinus. Anatomic study, with consideration of the clinical significance of the structured characteristics of the sphenoid sinus. Arch Otolaryngol 34:225-253, 1941

24. Vergoni G, Antonelli V, Veronesi V, Servadei F: Spontaneous cerebrospinal fluid rhinorrhoea in anteromedial temporal occult encephalocele. Br J Neurosurg 15:156-158, 2001

25. Wormald $P$ J, McDonogh M: Bath-plug' technique for the endoscopic management of cerebrospinal fluid leaks. J Laryngol Otol 111:1042-1046, 1997

26. Yucel A, Degirmenci B, Yilmaz MD, Altuntas A: [Spontaneous trans-sphenoidal encephalocele presenting with nontraumatic cerebrospinal fluid rhinorrhea (case report). Tani Girisim Radyol 10:196-199, 2004 